\title{
Morphotectonics and sedimentation in convergent margin basins: An example from juxtaposed marginal sea basin and foreland basin, Northern South China Sea
}

\author{
Ho-Shing Yu* Z Zehn-Yin Huang \\ Institute of Oceanography, National Taiwan University, Taipei, Taiwan
}

Available online 17 November 2007

\begin{abstract}
Using reflection seismic profiles and bathymetric mapping this paper reveals the tectonic-sedimentary characteristics of the convergent margins in the northern South China Sea, where it is strongly related to flexure of Chinese rifted margin and overthrust of Taiwan orogen. Convergent margin tectonics of the South China Sea near southern Taiwan is characterized by a progressively northward transition from oceanic subduction along the Manila Trench to the incipient collision zone offshore southern Taiwan where the continental crust of the Eurasian plate subducts beneath the Philippine Sea plate. North of $21^{\circ} \mathrm{N}$, dip angles of the Benioff zone increase up to $80^{\circ}$ in the incipient collision zone where the Manila Trench becomes shallower, gradually loses its morphological identity and finally merges into the nearly $\mathrm{N}-\mathrm{S}$ trending Penghu Canyon. Convergent margin tectonics in the initial collision zone in SW Taiwan is manifested by the beginning of flexure of the Chinese margin under the westward migrating overthrust belt of Taiwan, forming two distinct basins. On the passive Chinese margin, the marginal sea basin becomes smaller and is underlain by the South China Sea Slope, while on the active Taiwan margin, a wedge-top basin has formed above the frontal thrust sheets of the Taiwan orogenic wedge. Sediments derived from the Taiwan orogen progressively overlie the strata of the passive Chinese margin, resulting in sediment thickening and basin shallowing from south to north. Sedimentary facies shows that offshore deep-water mud is gradationally overlain by shallow marine sediments. Sediments of the wedge-top basin are being actively deformed into mud diapiric intrusions and a series of west-vergent thrusts and folds with their associated piggy-back basins, resulting in irregular topography of the sea floor with alternating sea ridges and troughs. Pliocene-Quaternary strata of the passive Chinese margin are a little deformed under the westward compression induced by the arc-continent collision in the southern Taiwan. The slope profile of the passive Chinese margin is characterized by a sigmoidal curvature, representing a typical primary depositional setting of a passive margin. Slope canyons occur mainly on the upper slope and cut the sea floor, resulting in irregular topography and representing effects of erosion.

Being under the initial arc-continent condition, the offshore SW Taiwan has experienced the transition from a rifted margin to an overthrust belt and becomes a foreland basin, which is acting as a catch basin for orogenic debris derived from SW Taiwan. Arguments from tectonics and sedimentation suggest that the Koping shelf-slope region is considered to be an immature foreland basin rather than an accretionary wedge. More specifically, the Kaoping shelf-slope can be regarded as a depositional wedge top where exists an overlap area between rapid sedimentation and active deformation of the Kaoping shelf-slope sediments in the external orogenic wedge of southern Taiwan.
\end{abstract}

(c) 2007 Elsevier B.V. All rights reserved.

Keywords: Convergent margin tectonics; Foreland sedimentation; Wedge-top basin; Taiwan; South China Sea

\footnotetext{
* Corresponding author.

E-mail address: yuhs@ntu.edu.tw (H.-S. Yu).
}

\section{Introduction}

\subsection{Tectonic setting}

The island of Taiwan is located on the eastern margin of the Asian continent bordering the Philippine Sea to the east and the South China Sea to the southwest (Fig. 1, inset at NW corner). The western Taiwan foreland basin has developed through the 


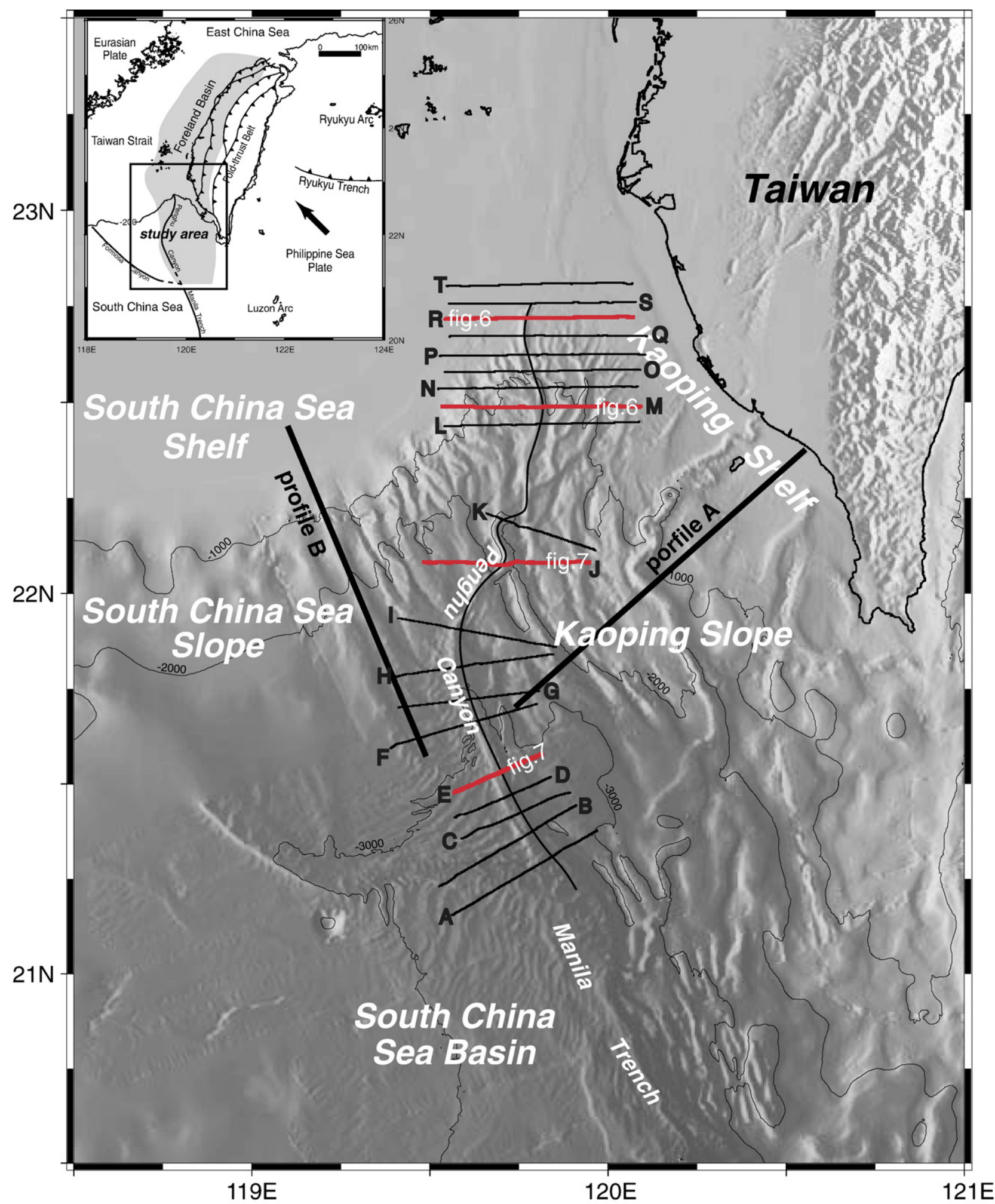

Fig. 1. Tectonic setting of the island of Taiwan showing that the Taiwan orogen is located between the Eurasian plate and the Philippine Sea plate (upper left inset). The study area off southwestern Taiwan in the northern South China Sea is mainly the slope region between the South China Sea Shelf and deep basin floor at the northern end of the Manila Trench. The isobaths of both slopes on the passive Chinese margin and the active Taiwan margin, respectively, cross cut in the north and form a triangle with an open end to the south. The study area in the northernmost South China Sea is represented by the juxtaposed South China Sea Slope and Kaioping Slope. The intersection of these two submarine slopes is occupied by the nearly N-S trending Penghu Submarine Canyon which merges gradually southward into the Manila Trench. Bathymetric data and four-channel profiles were collected in the study area. Twenty seismic profiles labeled as A through T are oriented normal to the axis of the Penghu Canyon to investigate interactions between the Chinese passive margin and the submarine Taiwan orogenic wedge. 
closure of the northern part of the South China Sea during Pliocene-Quaternary time (Covey, 1984; Yu and Chou, 2001; Lin and Watts, 2002) (Fig. 1, inset at NW corner). The formation of the paired foreland basin and mountain belt in Taiwan can be compared to the theoretical tectonic model of a convergent margin developing from a rifted margin to a foreland basin (Stockmal et al., 1986). The flexure of the Chinese rifted continental margin driven by overthrust load of the Taiwan orogen has resulted in an elongated depression subsequently filled by detritus shed from the uprising orogen. Because of the oblique convergence from the north to the south between the Eurasian and the Philippine Sea plates, the evolution of the western Taiwan foreland basin from Pliocene to the present day can be viewed along its strike. For example, Covey (1984) and Brusset et al. (1999) differentiate a mature foredeep in the north-central Taiwan from a youthful one in the south. The immature foreland basin in southern Taiwan covers the coastal plain and the offshore shelf-slope region off southwestern Taiwan (Yu, 2004); i.e., the present-day southern Taiwan and its offshore area are subjected to initial collision (Lallemand and Tsien, 1997; Willett et al., 2003). To the south of Taiwan, the northernmost part of the South China Sea is closing like a zipper by the southward propagation of the Taiwan collision zone (Yu, 2000; Sibuet and Hsu, 2004). Thus, the present-day South China Sea near Taiwan is undergoing in transition from collision in the north to subduction in the south, and has witnessed different geodynamic regimes during the Late Tertiary evolution of the South China Sea. Useful research results of the continent-ocean transition of the northern South China Sea and off southwestern Taiwan were summarized by Hsu and Sibuet (2004). As for a broader scope of continent-ocean interactions within East Asian marginal seas refers to Clift et al. (2004).

\subsection{Purpose}

The South China Sea is the largest marginal sea in the world and the sea floor in its northeast part is a rather complicated morphotectonic submarine feature between the passive margin of the Eurasian plate in the Southeast China and the active Taiwan orogen (Fig. 1). This paper describes distinct morphotectonic features and discusses relationships between tectonics, sedimentation and structural deformation in the incipient arc-continent collision zone off southwest Taiwan in the northern South China Sea. It intends to link the effects of individual convergent tectonics processes in southwest Taiwan to the larger-scale of the geodynamic models of convergent margin tectonics: the transition from a rifted basin to an overthrust belt and the resultant foreland basin development (Stockmal et al., 1986). Emphasis is placed on the interaction between frontal orogenic wedge and the passive margin.

\section{Data}

Bathymetric data and seismic reflection profiles were acquired in areas off southwestern Taiwan in the northernmost part of the South China Sea (Fig. 1) using the R/V Ocean Researcher I operated by National Taiwan University. A series of four-channel seismic profiles oriented normal to the basin axis of the northern South China Sea and across the intersection between the passive Chinese margin and the active Taiwan margin were used to emphasize interactions between the frontal parts of both the Chinese margin and the Taiwan orogenic wedge. Air gun arrays were deployed as the seismic source. The DFS-V floating gain digital system was used to record seismic signals. Seismic reflection data were processed using the SIOSEIS system and PROMAX software. Bathymetric data are acquired by the Simrad EH 500 Sonar. New bathymetric data are then integrated into the databank of bathymetry at the National Center for Ocean Research, National Taiwan University. The website of the databank of NCOR is http://www. ncor.ntu.edu.tw. Bathymetric charts in the study area were generated using GMT system (Wessel and Smith, 1991).

\section{Sea floor morphology}

The sea floor of northern South China Sea becomes shallow, narrows towards southwestern Taiwan, and gradually merges into the Taiwan Strait farther north (Fig. 1). The sea floor of the South China Sea north of $21^{\circ} \mathrm{N}$ is characterized by two broad slopes: the South China Sea Slope to the west and the Kaoping Slope to the east. The isobaths of the South China Sea Slope strike NE-SW and are aligned parallel with the regional structural trend of the southeast Chinese continental margin, while the bathymetric contours of the Kaoping Slope trend mainly NW-SE. The isobaths of both slopes cross cut in the north and form a triangle with an open end to the south. Numerous closely spaced unnamed canyons and gullies occur on the South China Sea Slope east of $119^{\circ} 45^{\prime} \mathrm{E}$
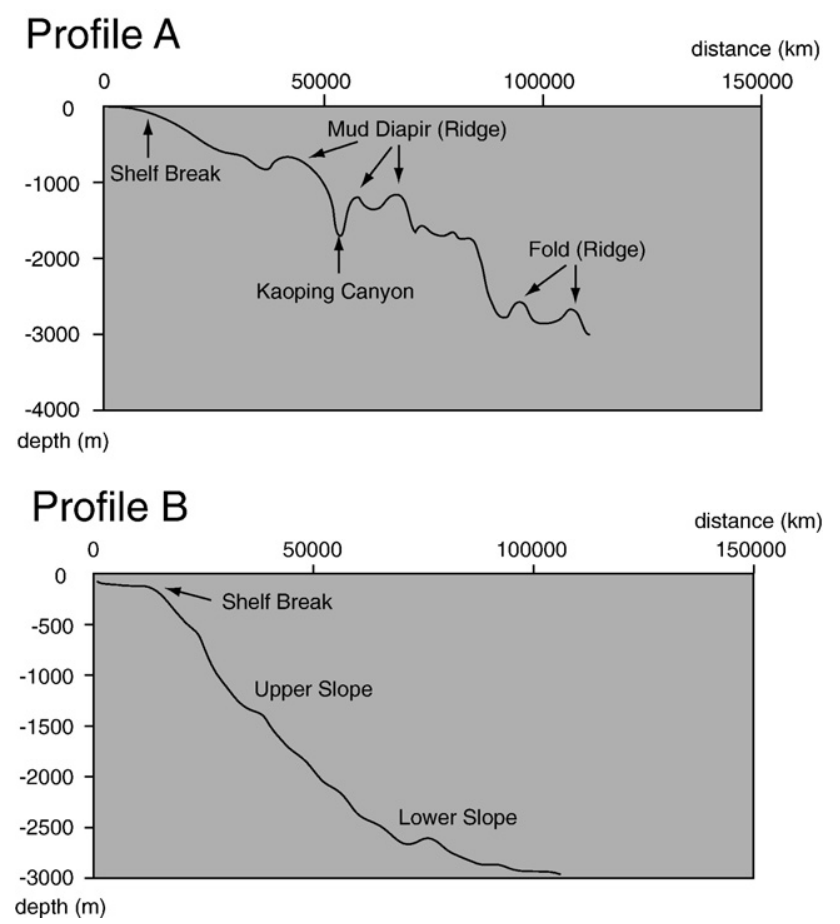

Fig. 2. Bathymetric profile A across the active Taiwan margin shows a slope profile of linear-like shape with great irregularities. In contrast, bathymetric profile B across the passive Chinese margin represents a typical slope profile with sigmoidal curvature like the passive margin of southwestern Africa (Adams and Schlager, 2000). Locations of profiles A and B are shown in Fig. 1. 

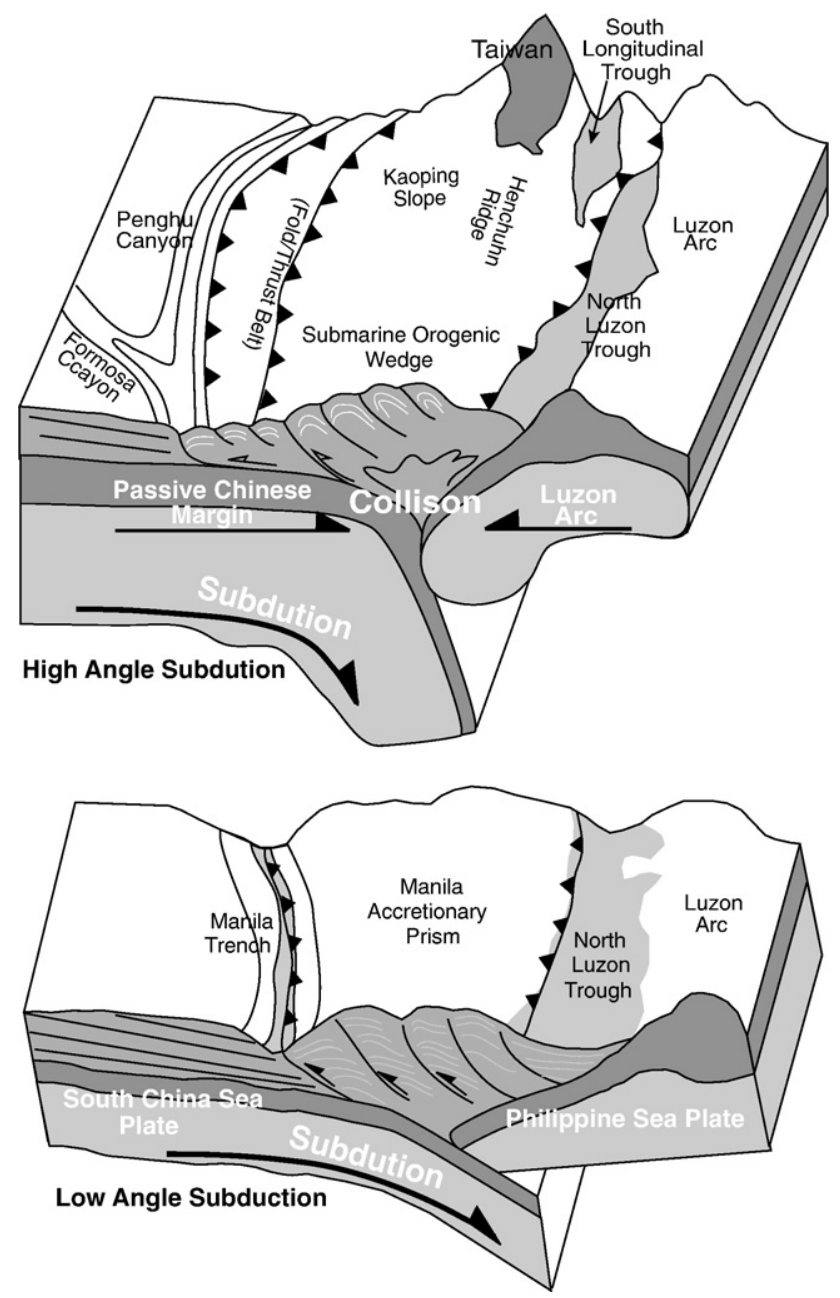

Fig. 3. Schematic diagram showing the transition from subduction to initial collision in the Penghu Canyon-Manila Trench transition zone off southwest Taiwan. The subduction angle of the South China Sea oceanic crust beneath the Philippine Sea plate is about $30^{\circ}$ at the $16^{\circ}-18^{\circ} \mathrm{N}$ along the Manila Trench (lower panel). The east-dipping angle of the Eurasian plate beneath the Philippine Sea plate increases to a maximum of $80^{\circ}$ at $20^{\circ}$ to $22^{\circ} \mathrm{N}$ in southern Taiwan where the continental crust tends to resist to subduction, initiating arc-continent collision between the Chinese margin and the Luzon Arc (upper panel).

(Fig. 1). They are typical slope canyons without any connection to the rivers along the Chinese coast. These canyons occur mainly on the upper slope and cut the sea floor, resulting in highly irregular topography and corresponding erosional features. In contrast, fewer canyons occur on the Kaoping Slope. The Kaoping Canyon, the largest one among others, is the seaward continuation of the Kaoping River, the second largest river in Taiwan, draining the coastal plain in southwestern Taiwan. This canyon deeply incises the narrow Kaoping Shelf and extends to the upper slope around $1000 \mathrm{~m}$ water depth, where it changes to run southeast, and finally ends at the northern Manila Trench (Liu et al., 1993). The Kaoping Canyon turns out to be the most prominent morphological features on the sea floor of the Kaoping Slope (Fig. 1). It is noted that another submarine canyon, the Penghu Submarine Canyon, is located right along the intersection between these two slopes. The Penghu Canyon begins at the margin of the slopes near the $200 \mathrm{~m}$ isobath, runs southwards sinuously and finally merges into the Manila Trench (Yu and Chang, 2002).

The continental shelves on both sides of the Penghu Canyon in the northernmost part of the South China Sea are quite different. The relatively flat South China Sea Shelf extends seaward more than $200 \mathrm{~km}$ before it reaches the shelf edge about 130-150 m water depth (Figs. 1 and 2). In contrast, the Kaoping Shelf on the Taiwan margin is a relatively narrow ( $\sim 20 \mathrm{~km}$ wide) and shallow ( $\sim 80$ m deep) platform (Yu and Chiang, 1997). The significance of shelf width in sedimentation is discussed below. Bathymetric map shows that the South China Sea Slope has a slope discontinuity at water depth of about $2000 \mathrm{~m}$ (Fig. 1). The upper slope between 200 and $2000 \mathrm{~m}$ water depth is characterized by an average slope angle of $2.46^{\circ}$ while the lower slope between 2000 to $3000 \mathrm{~m}$ in water depth is characterized by a relatively gentle slope angle of about $0.86^{\circ}$. The slope profile shows a sigmoidal shape (Fig. 2, Profile B). The Kaoping Slope has a slope profile with a discontinuity at water depth of about $2000 \mathrm{~m}$ (Fig. 2, Profile A). The upper slope between 200 to $2000 \mathrm{~m}$ water depth is characterized by an average slope angle of $1.4^{\circ}$, while the slope angle of the lower slope between 2000 and $3000 \mathrm{~m}$ water depth increases to about $1.93^{\circ}$. The slope profile shows a straight line with irregularities.

Around $21^{\circ} 15^{\prime} \mathrm{N}$, the Penghu Canyon merges gradually into the Manila Trench from the north (Fig. 1). The transition from the canyon to the trench at this intersection is similar to that from the Markham Canyon to New Britain Trench in western Solomon Sea (Galewsky and Silver, 1997). The characteristics of morphology of the Manila Trench change to channel shape showing broad trough and low relief.

\section{Morphotectonic characteristics of subduction-collision transition}

The surface collision tip between the Luzon Arc and the Chinese margin is suggested at the Penghu Canyon-Manila Trench transition (Yu, 2004) similar to the collision tip at the junction of the Trobriand Trough and the New Britain Trench in the western Solomon Sea (Galewsky and Silver, 1997). The subduction angle of the Eurasian plate beneath the Philippine Sea plate is about $30^{\circ}$ at the $16^{\circ}-18^{\circ} \mathrm{N}$ along the Manila Trench while the east-dipping band increases to a maximum of $80^{\circ}$ at $20^{\circ}$ to $22^{\circ} \mathrm{N}$ (Fig. 3). To the south of the canyon-trench transition, the South China Sea oceanic crust is subducting eastwards beneath the Luzon Arc, forming the Manila Trench. Pelagic sediments of the South China Sea are accreted to form the Manila accretionary prism along the trench. To the north of the canyon-trench transition, sediments derived from the Taiwan orogen are transported to the South China Sea and are deformed

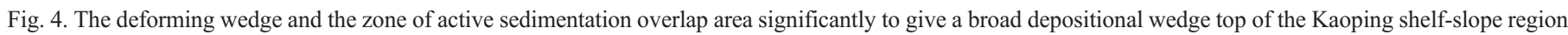

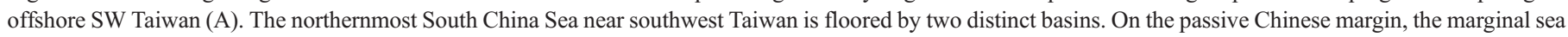

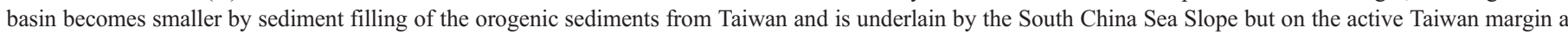

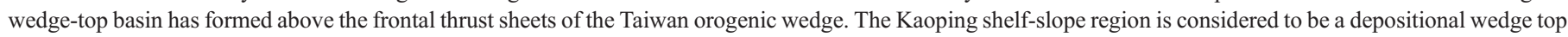
after Ford (2004) (B). 


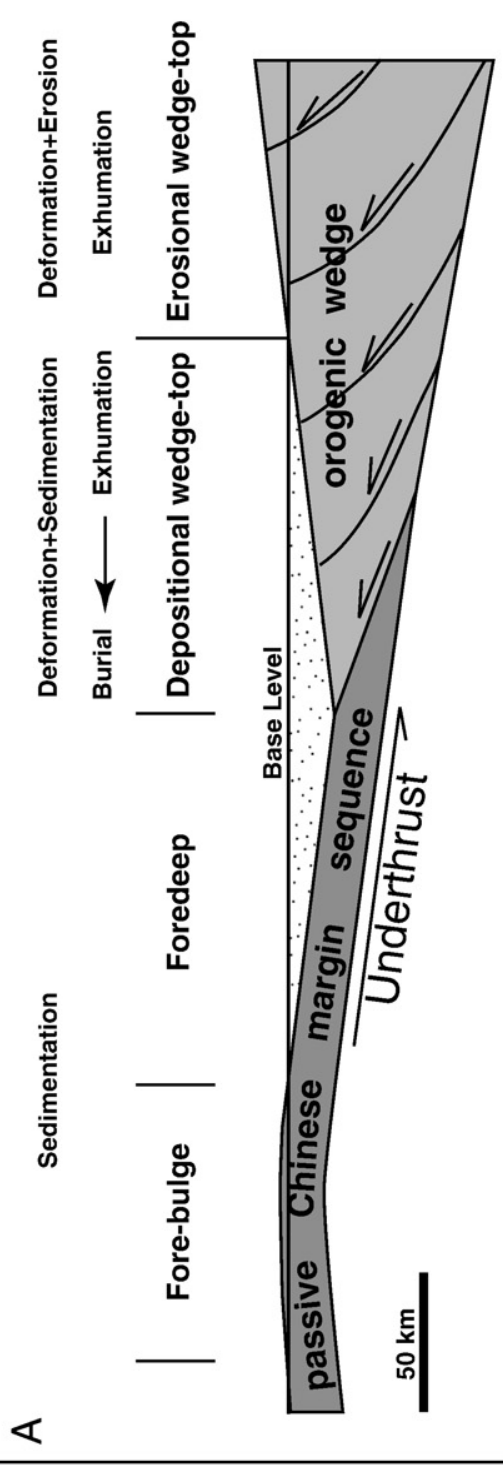

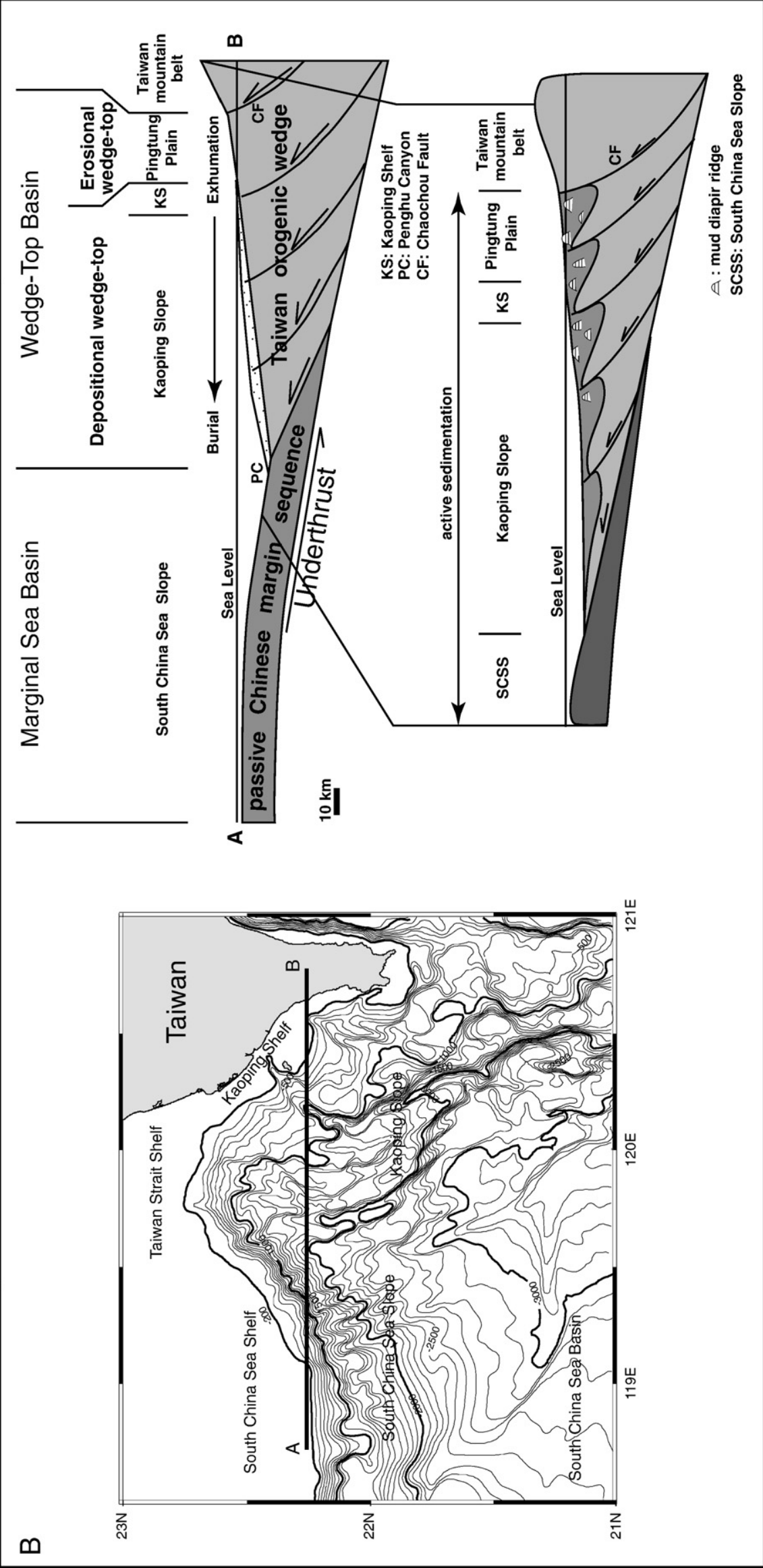




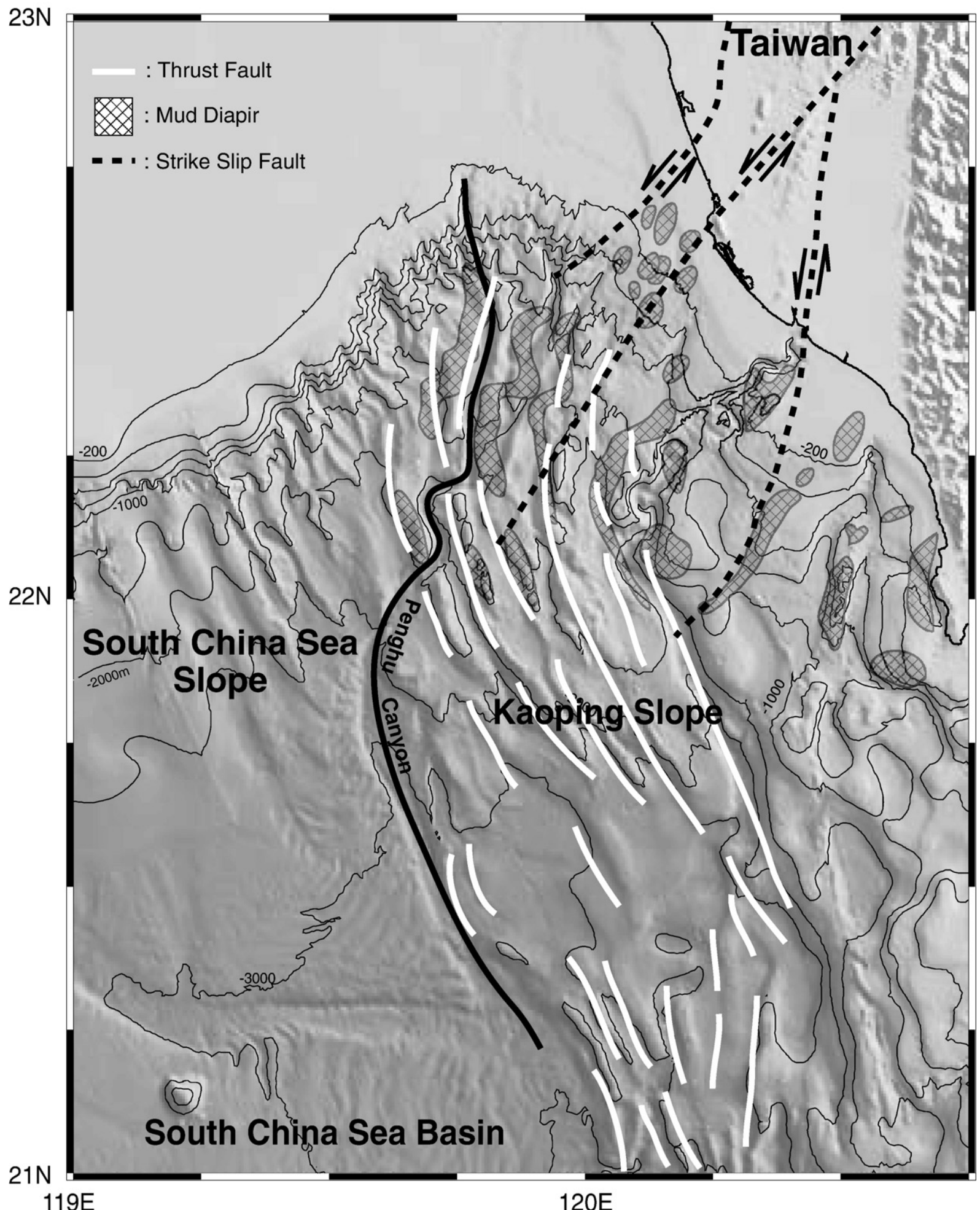

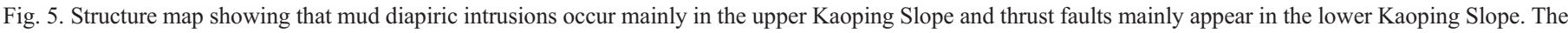

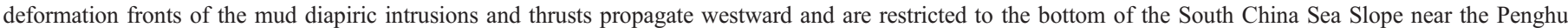
Canyon.

syn-depostionally into folds and thrusts associated with the Kaoping Slope (Fig. 3, upper panel).

In the incipient collision zone north of $21^{\circ} 30^{\prime} \mathrm{N}$, the physiography, stratigraphy and structures are the result of convergent margin tectonic processes by which the passive Chinese margin has been flexed by westward migrating overthrut belt of Taiwan, forming two distinct basins. On the Chinese margin, the marginal sea basin has been shrinking by filling sediments derived from the Taiwan orogen and is underlain by the South China Sea Slope. On the Taiwan margin, a wedge-top basin has formed above the 
frontal thrust sheets of the Taiwan orogenic wedge (Fig. 4). Relationships between morphology, structures and sedimentation of the convergent tectonics between the passive margin and the advancing orogenic wedge are discussed as follows.

\section{Morphology and structural deformation}

Four seismic profiles across the Penghu Canyon combined with distribution of structures are used to show the connection

\section{Profile R}

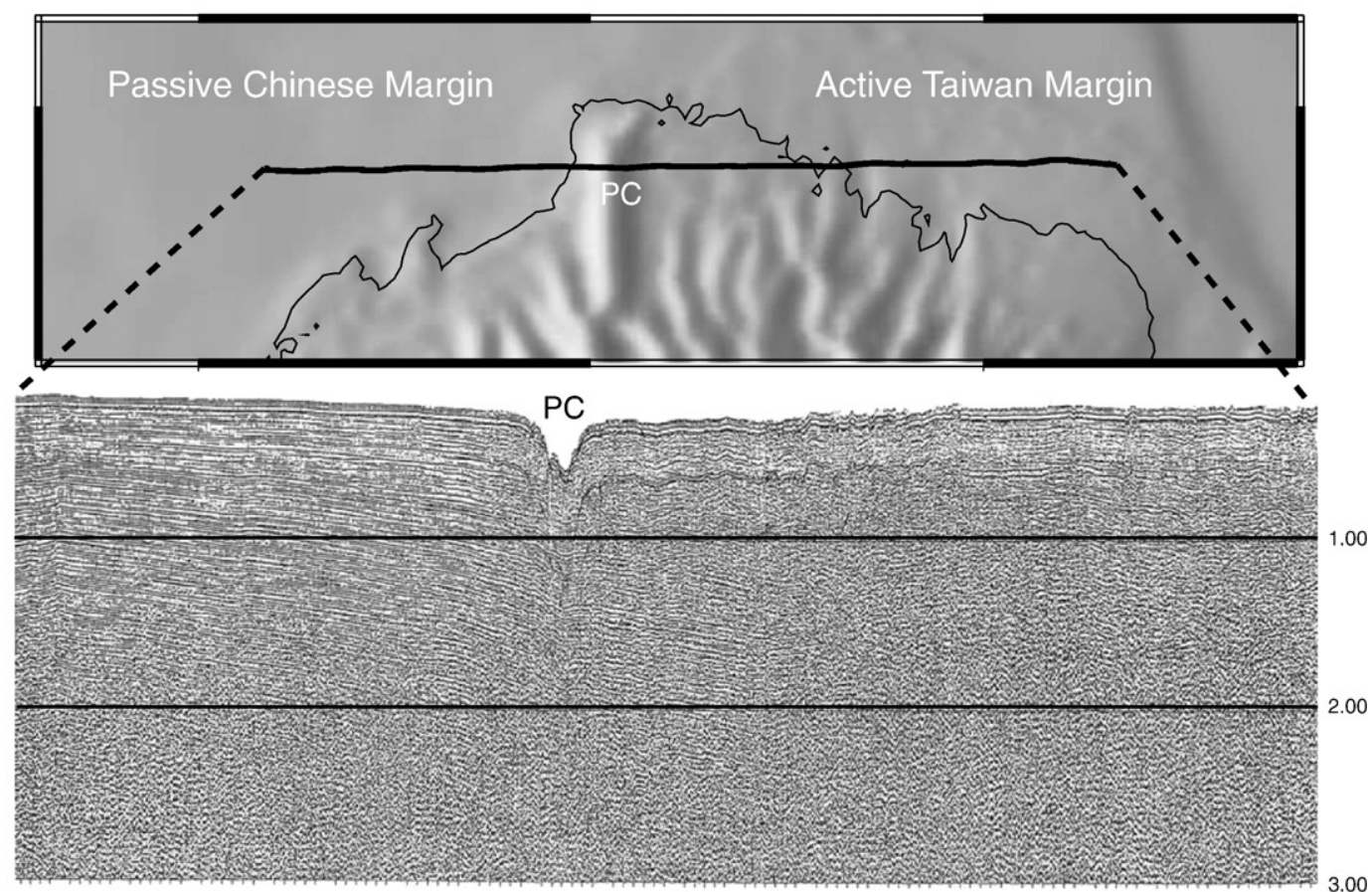

\section{Profile M}

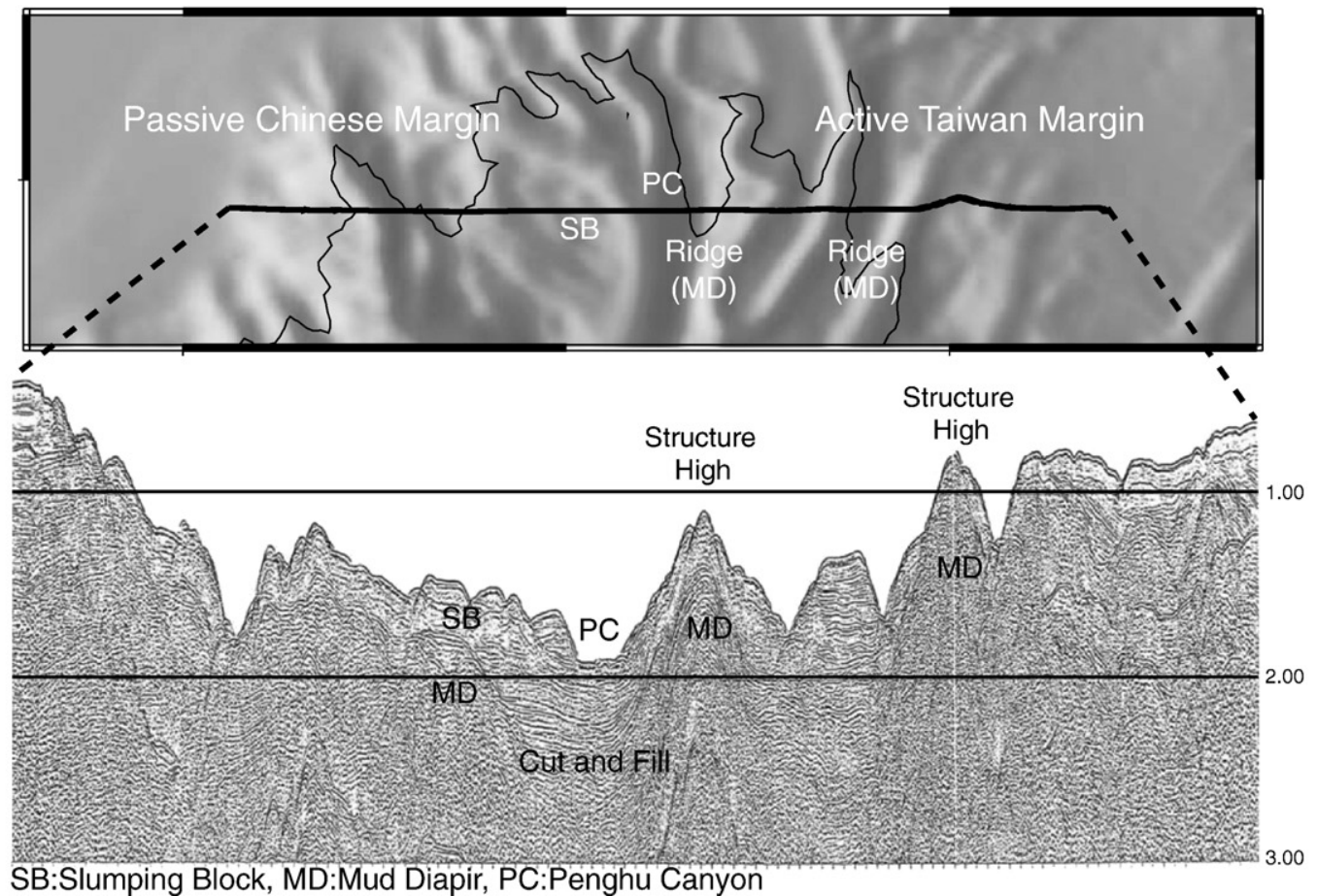

Fig. 6. Seismic profiles R and M show the linkage of the submarine morphology to the structural deformation in the incipient collision zone. Discussions are in the text. Locations of profiles $\mathrm{R}$ and $\mathrm{M}$ are shown in Fig. 1. 
of the submarine morphology to the structural deformation in the incipient collision zone. Fig. 5 shows that the mud diapiric intrusions occur mainly in the upper Kaoping Slope and thrust faults mainly appear in the lower Kaoping Slope. The defor- mation fronts of the mud diapiric intrusions and thrusts propagate westward and are restricted to the lower slope area of the South China Sea Slope near the Penghu Canyon. In contrast, the passive Chinese margin is a little deformed by the westward
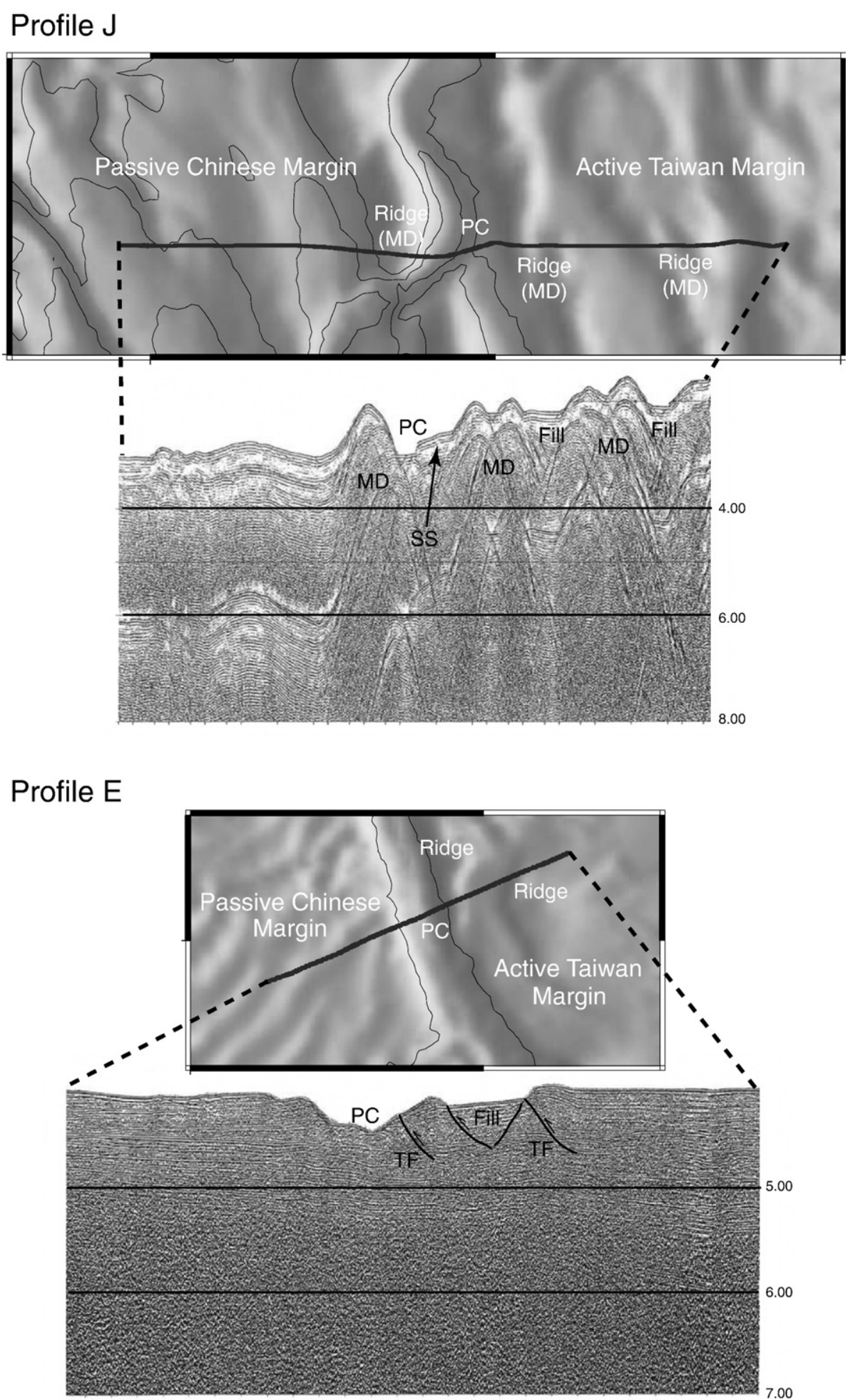

SS:Slumping/Sliding, MD:Mud Diapir, PC:Penghu Canyon, TF:Thrust Fault

Fig. 7. Seismic profiles J and E show that mud diapiric intrusions and thrust faults produced alternating submarine ridges and troughs, which are partially filled by sediments. Locations of profiles $\mathrm{J}$ and $\mathrm{E}$ are shown in Fig. 1. 
compression induced by the arc-continent collision in southern Taiwan.

Seismic profile $\mathrm{R}$ is located at the head of the Penghu Canyon and across the shelf-upper slope at water depths around $200 \mathrm{~m}$ (Fig. 6). Seismic characteristics indicate that the passive Chinese margin is characterized by continuous, parallel and divergent reflectors dipping eastwards. The uppermost reflector is relatively flat, reflecting a relative smooth sea floor as shown on the corresponding location of the bathymetric profile. In contrast, the seismic facies of the active Taiwan margin is characterized by discontinuous and sub-parallel reflectors in the upper part (shallower than $1.0 \mathrm{~s}$ ) of the profile, reflecting a relatively low-relief sea floor. The Penghu Canyon appears as a small V-shaped trough formed by down-cutting erosion, which can be evidenced by terminated reflectors against canyon walls. It is noted that the head of the Penghu Canyon on the bathymetric map is indicated by the $\mathrm{N}-\mathrm{S}$ trending coupled black and white stripe (Fig. 6). The head of the Penghu Canyon is shown as a black stripe as the light shed from the east. Farther south, seismic profile M (Fig. 6) lies across the upper slope region at water depth up to $1400 \mathrm{~m}$ deep and shows that the slope areas are characterized by distorted and chaotic seismic facies. Apparently, mud diapiric intrusions penetrate upward to reach the sea floor, forming structural highs. Slump blocks occur commonly on the upper slope as shown on the toe of the passive Chinese margin to the west of the Penghu Canyon. It is suggested that uplifting of the mud diapirs accompanied by erosional slumping and/or sliding produced highly irregular sea floor topography, which is characterized by

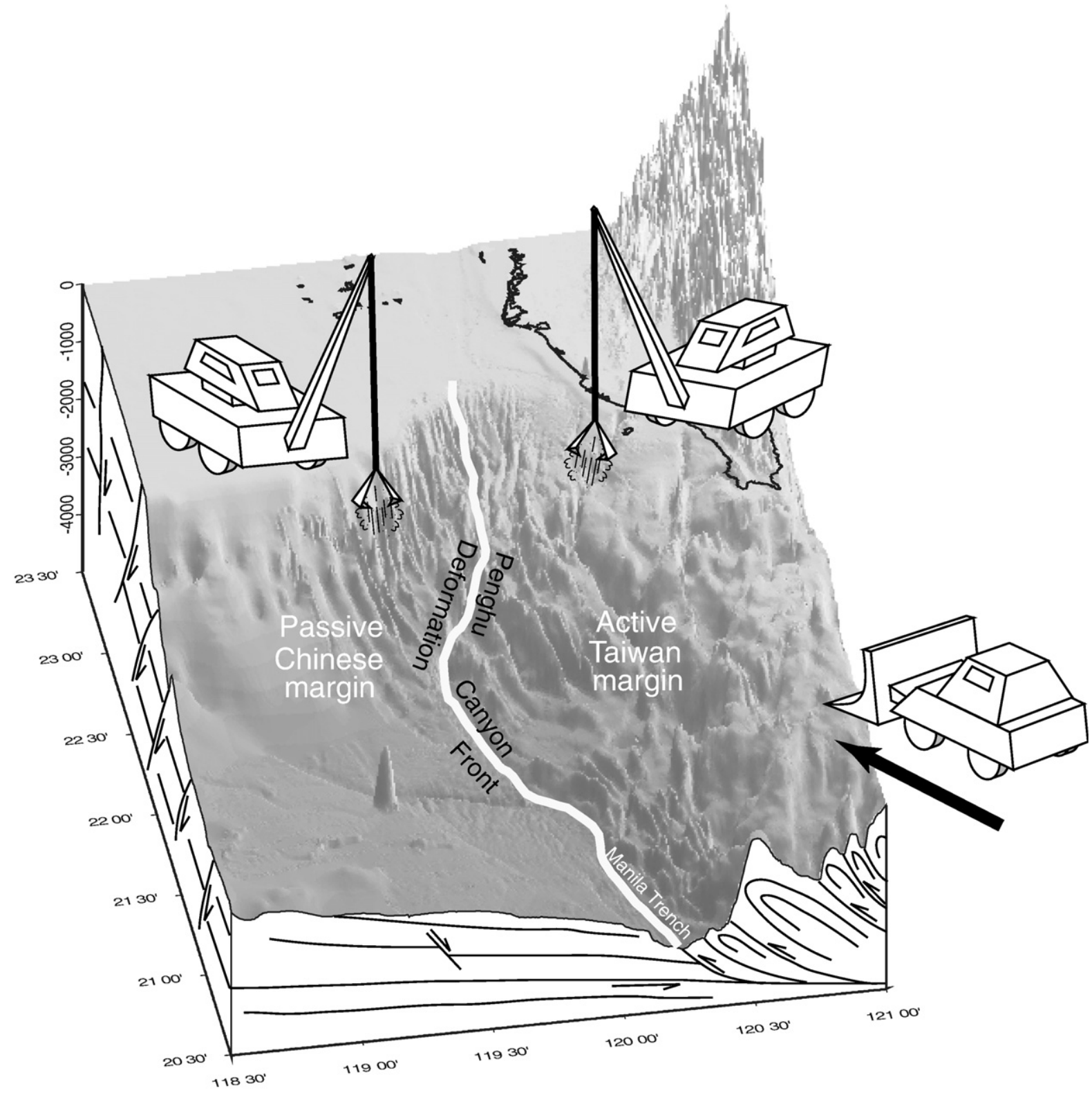

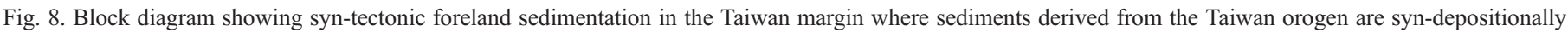

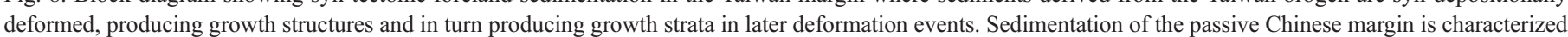
by regional subsidence and progradation of sediments and modified by surface erosive processes. 
alternating ridges and troughs. The sea ridge formed by mud diapiric intrusion immediately east of the Penghu Canyon is represented by a north-south trending white stripe (light shed from the east) and the accompanied Penghu Canyon to the west is shown as a black stripe (Fig. 6). It is noted that troughs between sea ridges are characterized as V-shaped without sediment filling at their bottoms on the seismic cross sections, indicating relatively intense mass-wasting movements on the sea floor. Only the

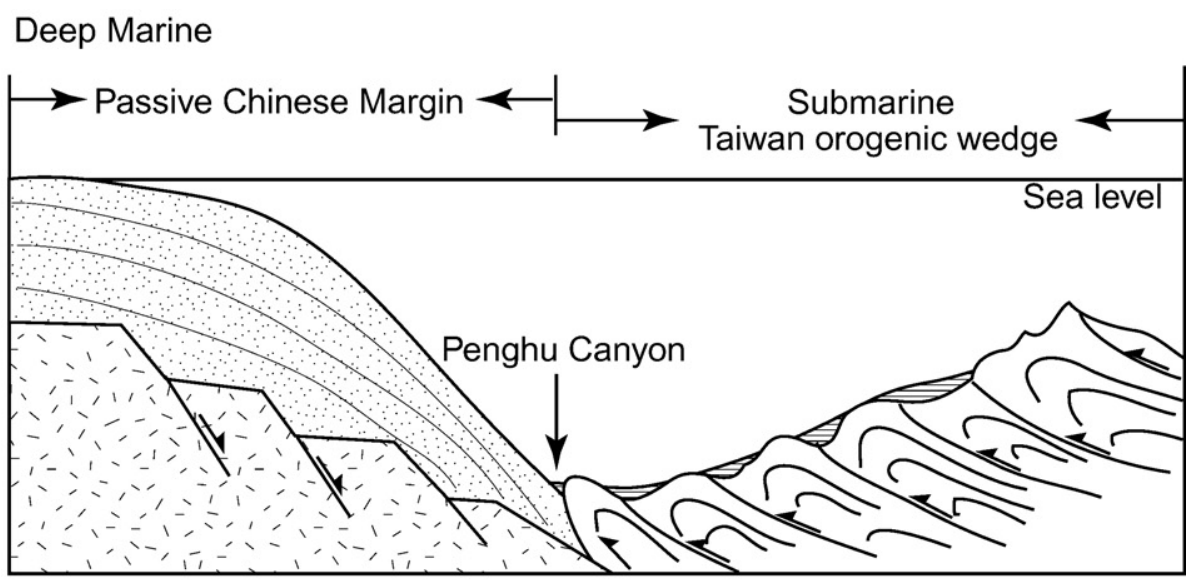

Hemipelagic

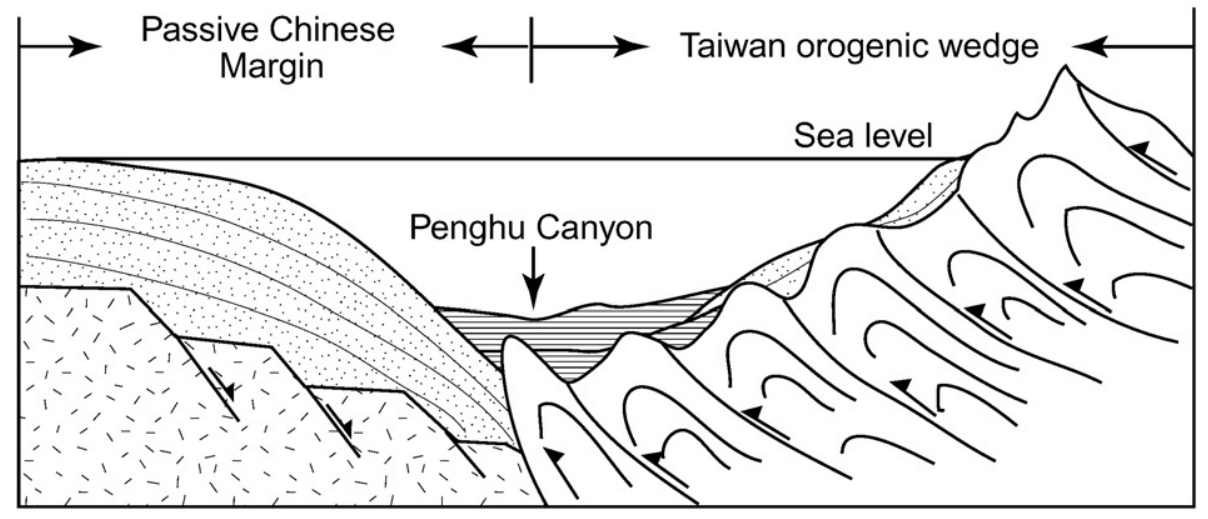

Shallow Marine

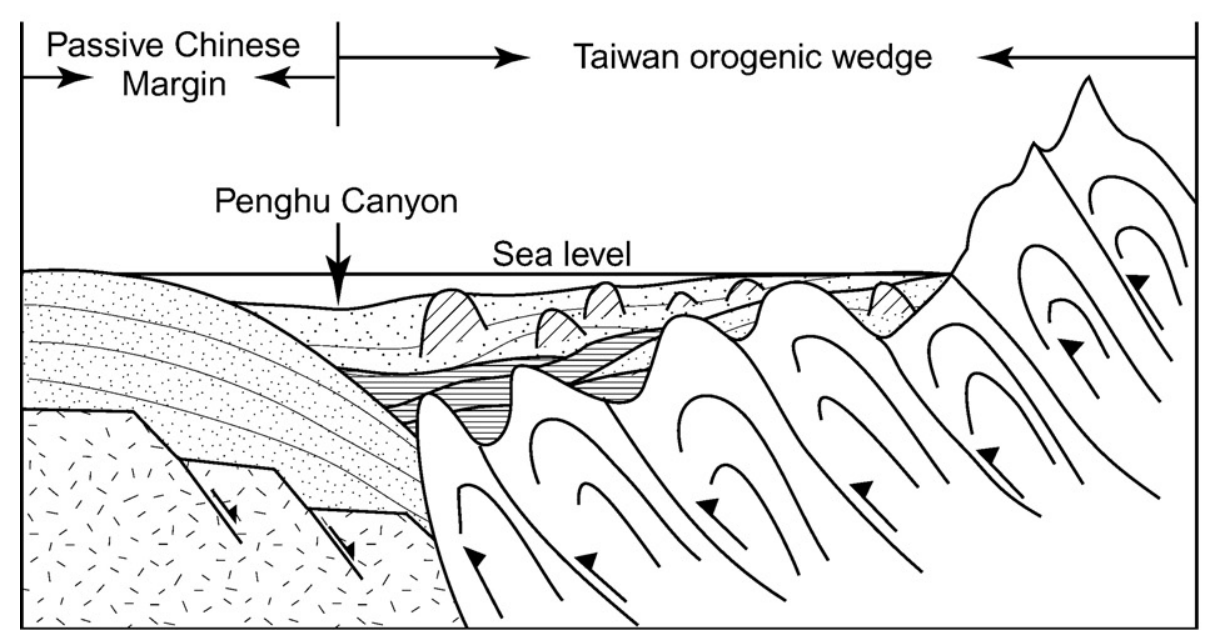

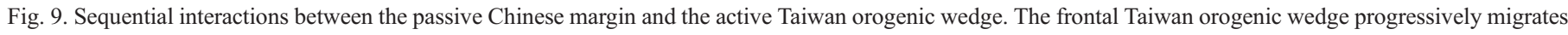

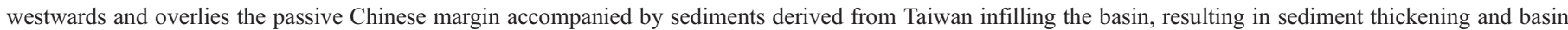

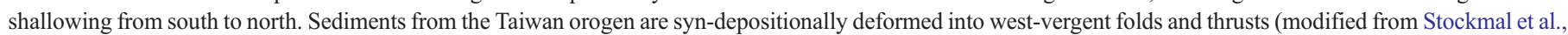
1986, Fig. 1). 
bottom of the Penghu Canyon is partially filled with sediment to form a flat reflector, a common cut-and-fill feature in the submarine canyons (McGregor, 1981).

Farther south seismic profile $\mathrm{J}$ located in the slope region at water depth of about $2500 \mathrm{~m}$ indicates that the lower slope of the Kaoping Slope is mainly deformed into closely spaced mud diapirs and thrust faults. These mud diapirs occur mainly in the Kaoping Slope and penetrate upward to reach the sea floor, forming lowrelief sea ridges (Figs. 5 and 7). It is noted that the troughs between these sea ridges are partially filled with sediments, producing lowrelief alternating ridge and trough topography. The topographic ridge west of the Penghu Canyon is represented as the $\mathrm{N}-\mathrm{S}$ trending white stripe on the bathymetric map (Fig. 7). The Penghu Canyon is shown as the $\mathrm{N}-\mathrm{S}$ trending black stripe. Seismic profile $E$ is located at the lower reach of the Penghu Canyon and north of the collision tip of the incipient collision zone (Fig. 7). West of the Penghu Canyon lies the South China Sea Slope of the passive Chinese margin where it is characterized by continuous and parallel reflectors on the seismic profiles. The sea floor is relatively smooth. East of the Penghu Canyon sediments of the Kaoping Slope are deformed into west-vergent thrust faults and a small piggy-back basin between the thrust faults. The thrust faults form low-relief topographic ridges. On the bathymetric map, the Penghu Canyon is represented as a NW-SE trending black stripe and the western wall of the Penghu Canyon is shown as the white stripe parallel with the canyon. The low-relief ridge east of the Penghu Canyon is represented by a relatively narrow white stripe (Fig. 7).

Seismic characteristics shown on these four profiles combined with the regional structural map (Fig. 5) suggest that the sea floor morphology off southwestern Taiwan in the northern South China Sea is strongly influenced by structural deformation accompanied with surface erosion by mass-wasting processes.

\section{Foreland syn-tectonic sedimentation versus passive margin sedimentation}

During Late Pliocene-Quaternary, exhumation of the Taiwan orogen through rapid uplift and erosion has produced abundant siliciclastic sediment to fill the Pingtung Plain and the Kaoping shelf-slope region, where have been the wedge-top basin on the submarine frontal orogenic wedge of Taiwan (Sun and Liu, 1993; Fuh, 1997, Chiang et al., 2004). Apparently, sediments supplied by the onshore Kaoping River drainage have filled up the Pingtung Plain and excess sediments have been delivered to the offshore Kaoping shelf-slope region (Fig. 8).

Here we emphasize the significance of sedimentation on the very narrow and shallow Kaoping Shelf and the connection of the Kaoping River to the Kaoping Canyon. It is noted that the major part of river sediment load ( $>80 \%$ ) tends to be accumulated off narrow shelf $(<20 \mathrm{~km}$ wide $)$ of collision margins through gravitydriven transport in a regional scale (Walsh and Nittrouer, 2003). It is expected that the Kaoping Shelf of about $10 \mathrm{~km}$ wide in a collision margin between the Luzon Arc and the Chinese margin would accumulate less than $20 \%$ of the sediments derived from the Kaoping River and more than $80 \%$ of the sediments should be transported basinwards and accumulated on the Kaoping Slope. However, since the mouth of the Kaoping River is connected to the Kaoping Canyon large amount of river should be directly delivered to the Kaoping Canyon rather than to the Kaoping Shelf, especially during flood events. It appears that the Kaoping Canyon and the Kaoping Shelf receive sediments entirely from the Kaoping River drainage areas. Furthermore, the head of the Kaoping Canyon has high capacity of triggering hyperpycnal flows especially during flood events (Liu et al., 2002). In turn the gravity-driven flows in the canyon intensely erode the canyon bottom farther down-canyon, resulting in a prominent erosional trough on the sea floor from the Kaoping River mouth to the northern Manila Trench (Fig. 1). In addition, sediments deposited on the Kaoping Shelf and Kaoping Slope regions are syn-depositionally deformed, producing growth structures, which are manifested by growth strata, are formed by syn-depositional deformation (McClay, 1992).The distribution of growth structures of mud diapirs and west-vergent fold-and-thrust faults are shown in Fig. 5. The growth strata appear in four relatively large piggy-back basins, which are distributed in an area up to $50 \mathrm{~km}$ wide on the shelf and upper slope regions which have been regarded as the wedge-top depozone of southwestern Taiwan (Chiang et al., 2004, Fig. 9). The active Taiwan margin is characterized by foreland sedimentation on a deforming submarine orogenic wedge with the formation of growth structures and associated growth strata.

Because of the lack of river drainage there is almost no supply of terrestrial material to the South China Sea Shelf (Fig. 1). In addition, the South China Sea Shelf is relatively wide $(>300 \mathrm{~km})$ and more than $80 \%$ of the accumulated sediments would be river derived (Walsh and Nittrouer, 2003). Therefore, the South China Sea Slope has received limited amount of sediment from the Chinese mainland. Instead, the submarine slope of the Chinese margin is deeply eroded into canyons and other smaller channels and gullies, forming pathways of transporting outer shelf and upper slope sediments down to the basin floor. Hence, the sedimentation of the passive Chinese margin is characterized by regional subsidence and progradation of sediments as evidenced by continuous, parallel and slightly divergent reflectors dipping basinward (Fig. 8) and is modified by surface erosive processes (Profile E, Fig. 7).

\section{Interactions between orogenic wedge and passive margin}

The interactions between Taiwan orogenic wedge and the passive Chinese margin are schematically summarized in Fig. 9. In the area near the collision tip where the Manila Trench progressively merges into the Penghu Canyon relatively thin deep-marine (water depth $>3000 \mathrm{~m}$ ) sediments were deposited on the deforming submarine Taiwan orogenic wedge (Fig. 9, upper panel). The age of the distal foreland sediments is probably Early Pleistocene (Hong, 1997). Pliocene foreland basin sediments could have been incorporated into the deforming orogenic wedge either during or after deposition. The frontal orogenic wedge of Taiwan began to override the Chinese margin as evidenced by seismic characteristics shown on Profile E. The deep-marine sediments are syndepositionally deformed into west-vergent thrust faults, resulting in a relatively low-relief sea floor. In this initial collision stage the passive Chinese margin had not undergone flexural bending due to 
insufficient load of the Taiwan orogenic wedge (Lin and Watts, 2002). Due to being far away from the sediment source of the emergent Taiwan orogen the collision tip area received limited amount of sediment and remained a deep-marine setting. Farther north and closer to the Taiwan orogen the frontal orogenic wedge of Taiwan migrated farther to the west and overrode the toe of the passive Chinese margin (Fig. 9, middle panel). Increasing amount of sediment from the uplifted thrust wedge of Taiwan filled up the basin bottom, and formed a hemipelagic basin setting. The finegrained hemipelagic sediments were syn-depositionally deformed into closely spaced mud diapiric intrusions which penetrated upward to reach the sea bed and formed irregular sea floor topography as shown on Profile J. It is noted that the deformation front of the Taiwan orogenic wedge migrated across the Penghu Canyon and to the toe of the South China Sea Slope of the passive Chinese margin as shown on Profile J. It is demonstrated that the collision intensity increased from south to north. Farther north in the shelfupper slope region large amount of fine-grained sediments filled up the basin to a shallow marine setting (Fig. 9, lower panel). The shallow marine sediments were syn-depositionally deformed into mud diapiric intrusions, which were accompanied by intense erosion due to mass-wasting movements and resulted in a highly irregular sea floor with canyons and gullies as shown on seismic profile M. In the area proximal to the Taiwan orogen more sediment were available to fill the marine basin up to near sea level, as shown on Profile R. Sediment derived from the Taiwan orogen advanced farther westwards and overrode the outer shelf and slope of the passive Chinese margin. It is implied that the outer Chinese margin was depressed by the Taiwan orogenic loading.

Interactions between the active Taiwan and the passive Chinese margins are characterized by continued westward migration of the Taiwan orogenic wedge, which is overriding the outer shelf and slope regions of the passive Chinese margin. Sediments derived from the Taiwan orogen progressively overlie the strata of the passive Chinese margin, resulting in sediment thickening and basin shallowing from south to north. Sediments derived from the Taiwan orogen were dominated by fine-grained marine facies and syn-depositionally deformed into mud diapirs, folds and thrust faults. The Chinese margin is a little deformed by the compression due to arc-continent collision in the Taiwan region. However, flexure bending of the Chinese margin began to happen in the region north of $22^{\circ} 30^{\prime} \mathrm{N}$.

\section{Discussions}

The shape of slope profiles of continental margins has been considered as the first-order morphology and related mainly to characteristics of sediment influx, depositional processes and tectonic activities (Schlager and Camber, 1986; Pratson and Haxby, 1996; Adams and Schlager, 2000). Profile B across the passive Chinese margin represents a typical slope profile with sigmoidal curvature like the passive margin of southwestern Africa (Adams and Schlager, 2000). It is characterized by a sharp shelfbreak at water depth about $130 \mathrm{~m}$ and an inflection point at water depth around $1500 \mathrm{~m}$ in water depth at the upper-lower slope transition. The lower slope gradually flattens out towards basin floor with a concave-upward shape. The slope profile represents a typical pri- mary depositional setting of the passive margin, resulting from combined processes of progradational deposition of shallow marine sediments and regional thermal subsidence during Late Tertiary of the passive Chinese margin. In contrast, Profile A across the Taiwan margin shows a slope profile of linear-like shape with great irregularities. This slope profile has no sharp shelfbreak unlike that of the Profile B of the passive Chinese margin. Clearly, the secondorder morphological feature such as the large Kaoping submarine canyon produces a topographic relief more than $500 \mathrm{~m}$, causing the primary irregularity. Other irregularities of the profile are apparently related to disturbances from mud diapiric intrusions and their accompanied folding. The slope curvature of the Taiwan margin is greatly affected by tectonic activities, not due to the primary depositional setting.

The morphotectonic nature of the offshore SW Taiwan, including those of the major part of Kaoping shelf and slope, is debatable. There are two major arguments, the immature foreland basin and the accretionary wedge. The concept of an immature foreland basin for the offshore SW Taiwan was proposed by the study of Covey (1984), in which the foreland basin in southern Taiwan is extended into the Kaoping shelf-slope region without any supporting marine data; although the Pingtung Plain, the landward continuation of the Kaoping Shelf, is underlain by a foreland basin (Wu, 1993). Applying the nomenclature of a foreland basin system proposed by DeCelles and Giles (1996) and linking their concept to the Taiwan mountain building, Brusset et al. (1999) considered the southern Taiwan and offshore areas to be a foreland basin system, including a prevailing wedge-top depozone (e.g., the Pingtung Plain) and an infant foredeep depozone (i.e., the Kaoping Shelf and Kaoping Slope). Lin and Watts (2002) proposed that the southern Taiwan foreland basin is formed by yielding of the passive Chinese margin under a relative weak load of the Taiwan orogen. Later, Chiang et al. (2004) considered the Pingtung Plain, Kaoping Shelf and Kaoping Slope as a whole to be a wedge-top depozone, accompanied with the initial mountain building in southern Taiwan.

The idea of an accretionary wedge for the offshore SW Taiwan has evolved from the studies of mountain building in Taiwan (Suppe, 1981) and subduction along the Manila Trench in the northern South China Sea (Letouzey and Sage, 1988). Suppe (1981) suggested that the fold-and-thrust belt of western Taiwan is a much expanded accretionary wedge largely composed of Cenozoic continental margin sediments. Intuitionally, Letouzey and Sage (1998) extended the Manila accretionary wedge associated with the Manila Trench northward across the Kaoping Slope and into the Kaoping Shelf without any supporting marine data. Following the ideas of Suppe (1981) and Letouzey and Sage (1988), marine studies in offshore areas between southern Taiwan and northern Luzon either extended the Taiwan accretionary wedge into the offshore areas of southern Taiwan or continue the Manila accretionary wedge northward into the offshore areas of SW Taiwan (e.g., Reed et al., 1992; Liu et al., 1997, 2004). However, these studies presented no characteristic processes of offscraping sediment from the passive Chinese margin and accreting them into the overthrust belt of the Taiwan orogen.

The SW Taiwan region (Fig. 4) today comprises the Taiwan orogenic wedge, which has overthrusted the northern margin of the South China Sea. This margin represents an analogy to the 
convergent margin tectonics of Stockmal et al. (1986), illustrating the transition from the Chinese rifted margin to the overthrust belt of southern Taiwan and the development of an immature foreland basin in the offshore SW Taiwan. Robertson (1987) and Patton and O'Connor (1988) showed that the evolution of the Northern Oman Mountain foreland basin in the United Arab Emirates can be compared to the model of Stockmal et al. (1986). The Arabian continental margin and Tethys ocean underwent rifting in Permain and Triassic and formed a mature passive margin in Jurassic. As subduction began, the trench migrated toward the Arabian continent preceded by a flexural shallow platform. As the advancing overthrust impinged on the edge of the Tethys ocean, the crust was downflexed, creating a foredeep that filled mainly with deep-water sediments. As the thrust load of the Oman Mountain advanced more cratonward, the foredeep migrated over the Arabian rifted margin, the trench fill and accretionary wedge were later buried and incorporated into the base of the orogenic wedge. This is the same as in the SW Taiwan. During the most recent evolutional cycle in the northern South China Sea the Manila accretionary wedge and Manila Trench fills were completed buried and incorporated into the base of growing orogenic wedge of Taiwan and the accretionary wedge was destroyed but not expanded as speculated by Suppe (1981). Ultimately, the early accretionary wedge associated with the Manila Trench was abandoned and a new flexure regime occurred more toward the Chinese passive margin.

Being under the initial arc-continent condition, the offshore SW Taiwan has experienced the transition from a rifted margin to an overthrust belt and became a foreland basin. Therefore, the Koping shelf and slope region is considered to be an immature foreland basin rather than an accretionary wedge.

Downward flexing of the Chinese rifted margin due to a tectonically emplaced load by the Taiwan orogen results in an adjacent foreland basin off SW Taiwan, which acts a catch basin for the orogenic debris derived from SW Taiwan. Being proximal to the Taiwan orogen, the SW Taiwan foreland basin becomes the sink to receive sediments delivered from the Taiwan orogen. The source to sink link led Yu (2004) to suggest that the Kaoping shelfslope region offshore SW Taiwan is more likely to be an underfilled foreland basin rather than an accretionary wedge.

More specifically, according to Ford (2004), the Kaoping shelfslope region can be regarded as a depositional wedge top, which can be distinguished from the exposed and erosional part of the wedge top (Fig. 4). There is a wide overlap area between rapid sedimentation and active deformation of the Kaoping shelf-slope sediments in the external orogenic wedge of southern Taiwan (Fig. 4). Syn-sedimentary structures occurring in many foreland basins are widely referred to as growth structures (McClay, 1992). The intrusions of mud diapirs and west-vergent folds and thrust faults commonly found in the Kaoping shelf-slope, therefore, are considered as growth structures occurring above a growing deforming wedge. Two major tectonic factors control the characters and development of the external zones of the southern Taiwan orogen. These are the flexural bending of the underthrusting lithosphere plate (the South China Sea lithosphere) in response to imposed orogenic load of southern Taiwan and the deformation of sediments deposited over the wedge top. The further discussion of the interaction between these two factors is beyond the scope of this paper.

\section{Summary and conclusions}

Using reflection seismic profiles and bathymetric mapping this paper reveals the tectonic-sedimentary characteristics of the convergent margins in the northern South China Sea, where it is strongly related to flexure of Chinese rifted margin and overthrust of Taiwan orogen. The SW Taiwan region today comprises the Taiwan orogenic wedge, which has overthrusted the northern margin of the South China Sea. This margin represents an analogy to the convergent margin tectonics of Stockmal et al. (1986). It also can illustrate the transition from the Chinese rifted margin to the overthrust belt of southern Taiwan and the development of an immature foreland basin in the offshore SW Taiwan. Tectonics of the South China Sea near southern Taiwan exhibits a progressive northward transition from oceanic subduction along the Manila Trench to the incipient collision zone offshore southwestern Taiwan where the continental crust of the Eurasian plate subducts beneath the Philippine Sea plate. The shapes of slope profile of both the Chinese and Taiwan margins are quite different. The former shows a slope profile with sigmoidal curvature, representing a typical primary depositional setting of a passive margin. The latter shows a slope profile of linear-like shape with great irregularities, representing some effects of tectonic activities. The morphology, stratigraphy and structures of the juxtaposed margins are the result of convergent margin tectonic processes of which the passive Chinese margin has been flexed by westward migrating overthrust belt of Taiwan, forming two distinct basins. On the passive Chinese margin, the marginal sea basin becomes smaller and is underlain by the South China Sea Slope, while on the active Taiwan margin, a wedge-top basin has formed above the frontal thrust sheets of the Taiwan orogenic wedge.

Interactions between the submarine Taiwan orogenic wedge and the passive Chinese margin are characterized by continued westward migration of the Taiwan orogenic wedge, which is overriding the outer shelf and slope regions of the Chinese margin. Sediments derived from the Taiwan orogen progressively overlie the strata of the passive Chinese margin, resulting in sediment thickening and basin shallowing from south to north. Sediments derived from the Taiwan orogen are dominated by fine-grained marine facies and syn-depositionally deformed into mud diapirs, folds and thrust faults. The passive Chinese margin is a little deformed under the compression due to the arc-continent collision in the Taiwan region. However, flexure bending of the Chinese margin began to happen in the region north of $22^{\circ} 30^{\prime} \mathrm{N}$. Arguments from tectonics and sedimentation suggest that the Koping shelf-slope region is considered to be an immature foreland basin rather than an accretionary wedge. More specifically, the Kaoping shelf-slope region can be regarded as a depositional wedge top where an overlap area between rapid sedimentation and active deformation of the Kaoping shelf-slope sediments in the external orogenic wedge of southern Taiwan exists.

\section{Acknowledgements}

We thank crew and technicians onboard R/V Ocean Researcher I for collecting the marine data for this study. This research is financially supported by the National Science Council of Taiwan. 
We are grateful for using the bathymetry databank of NCOR for generating bathymetric charts for this research. Valuable comments and suggestions by Kenn-Ming Yang and one anonymous reviewer improved this manuscript greatly.

\section{References}

Adams, E.R., Schlager, W., 2000. Basic types of submarine slope curvature. J. Sediment. Res. 70, 814-828.

Brusset, S., Deramond, J., Souquet, P., Mouthereau, F., Deffontaines, B., 1999. Pro-foreland basin system linked to Taiwan mountain building. 4th Int. France-Taiwan Symposium, Montpellier, France, pp. 67-68. Abstract.

Chiang, C.S., Yu, H.S., Chou, Y.W., 2004. Characteristics of the wedge-top depozone of the southern Taiwan foreland basin system. Basin Res. 16, 65-78.

Clift, P., Wang, P.X., Kuhnt, W., Hayes, D., 2004. Continent-Ocean Interactions Within East Asian Marginal Seas. Geophys. Monograph 149, Amer. Geophys. Union, Washington, DC. 337 pp.

Covey, M., 1984. Lithofacies analysis and basin reconstruction, Plio-Pleistocene western Taiwan foredeep. Petroleum Geol. Taiwan 20, 53-83.

DeCelles, P.G., Giles, K.A., 1996. Foreland basin systems. Basin Res. 8, 105-125.

Ford, M., 2004. Depositional wedge tops: interaction between low basal friction external orogenic wedges and flexural foreland basins. Basin Res. 16, 361-375.

Fuh, S. C., 1997. Structural evolution of the oblique arc-continent collision on land and offshore southern Taiwan. National Taiwan University, Ph. D. Thesis, 166 pp.

Galewsky, Y., Silver, E.L., 1997. Tectonic controls on facies transitions in an oblique collision: The western Solomon Sea, Papua New Guinea. GSA Bull. 109, 1266-1278.

Hong, E., 1997. Evolution of Pliocene to Pleistocene sedimentary environments in an arc-continent collision zone: evidence from the analysis of lithofacies and ichnofacies in the southwestern foothills of Taiwan. J. Asian Earth Sci. 15, 381-392.

Hsu, S.K., Sibuet, J.C., 2004. Continent-Ocean Transition of the Northern South China Sea and Off Southwestern Taiwan. Mar. Geophys. Res. Special Issue, 25. $180 \mathrm{pp}$

Lallemand, S.E., Tsien, H.H., 1997. An introduction to active collision in Taiwan. Tectonophysics $274,1-3$.

Letouzey, J., Sage, L., 1988. Geological and structural map of eastern Asia, Scale 1:2,500,000. Amer. Assoc. Petrol. Geol., Tulsa, OK, USA.

Lin, A.T., Watts, A.B., 2002. Origin of the West Taiwan basin by orogenic loading and flexure of a rifted continental margin. J. Geophys. Res. 107 (B9), 1-19 ETG 2.

Liu, C.S., Lundberg, N., Reed, D.L., Huang, Y.L., 1993. Morphological and seismic characteristics of the Kaoping Submarine Canyon. Mar. Geol. 111, 93-108.

Liu, C.S., Huang, Y.L., Teng, L.S., 1997. Structural features off southwestern Taiwan. Mar. Geol. 137, 305-319.

Liu, C.S., Deffontaines, B., Lu, C.Y., Lallemand, S., 2004. Deformation patterns of an accretionary wedge in the transition zone from subduction to collision offshore southwestern Tawian. Mar. Geophys. Res. 25, 123-137.

Liu, J.T., Liu, K.J., Huang, J.C., 2002. The influence of a submarine canyon on river sediment dispersal and inner shelf sediment movements: a perspective from grain-size distributions. Mar. Geol. 181, 357-386.
McClay, K.R., 1992. Glossary of thrust tectonic terms. In: McClay, K.R. (Ed.), Thrust Tectonics. Chapman \& Hall, London, pp. 419-433.

McGregor, B.A., 1981. Ancestral head of Wilmington Canyon. Geology 9, 254-257.

Patton, T.L., O'Connor, S.J., 1988. Cretaceous flexural history of Northern Oman Mountain foredeep, United Arab Emirates. AAPG Bull. 72, 797-809.

Pratson, L.F., Haxby, W.F., 1996. What is the slope of the U. S. continental margin? Geology 24, 3-6.

Robertson, A., 1987. The transition from a passive margin to an Upper Cretaceous foreland basin related to ophiolite emplacement in the Oman Mountains. GSA Bull. 99, 633-653.

Reed, D.L., Lundberg, N., Liu, C.S., Kuo, B.Y., 1992. Structural relationship along the margins of the offshore Taiwan accretionary wedge: implications for accretion and crustal kinematics. Acta Geol. Taiwanica 30, 105-122.

Schlager, W., Camber, O., 1986. Submarine slope angles, drowning unconformities, and self-erosion of limestone escarpments. Geology 14, 762-765.

Sibuet, J.C., Hsu, S.K., 2004. How was Taiwan created? Tectonophysics 379, $159-181$.

Stockmal, G.S., Beaumont, C., Boutilier, R., 1986. Geodynamic models of convergent margin tectonics: transition from rifted margin to overthrust belt and consequence for foreland-basin development. AAPG Bull. 70, $181-190$.

Sun, S.C., Liu, C.S., 1993. Mud diapirs and submarine channel depositions in offshore Kaohsiung and Hengchun, southwest Taiwan. Petroleum Geol. Taiwan 28, 1-14.

Suppe, J., 1981. Mechanics of mountain building and metamorphism in Taiwan. Geol. Soc. China Mem. 4, 67-89.

Walsh, J.P., Nittrouer, C.A., 2003. Contrasting styles of off-shelf sediment accumulation in New Guinea. Mar. Geol. 196, 105-125.

Wessel, P., Smith, W.H.F., 1991. The GMT-System Version 2. Technical Reference and Cookbook, Scripps Inst. Oceanography, Univ. Calif., San Diego. 77 pp.

Willett, S.D., Fisher, D., Fuller, C., Yeh, E.C., Lu, C.Y., 2003. Erosion rates and orogen-wedge kinematics in Taiwan inferred from fission-track thermochronometry. Geology 31, 945-948.

Wu, L. C., 1993. Sedimentary basin succession of the Upper Neogene and Quaternary Series in Chishan area, southern Taiwan and its tectonic evolution. National Taiwan University, Ph. D. Thesis, 212 pp.

Yu, H.S., 2000. Closure of Manila Trench north of Latitude $21^{\circ} \mathrm{N}$ in transition of passive-convergent margin south of Taiwan. Acta Oceanogr. Taiwanica 38, $115-127$.

Yu, H.S., 2004. An under-filled foreland basin in the northern South China Sea off southwest Taiwan: incipient collision and foreland sedimentation. Gephys. Monograph Series 149, 159-173.

Yu, H.S., Chang, J.F., 2002. The Penghu Submarine Canyon off southwestern Taiwan: morphology and origin. Terrestrial, Atmospheric and Oceanic Sci. 13, 547-562.

Yu, H.S., Chou, Y.W., 2001. Characteristics and development of the flexural forebulge and basal unconformity of Western Taiwan Foreland Basin. Tectonophysics 333, 277-291.

Yu, H.S., Chiang, C.S., 1997. Kaoping Shelf: morphology and tectonic significance. J. Southeast Asian Earth Sci. 15, 9-18. 